\title{
A MILESTONE IN POLISH CISG JURISPRUDENCE AND ITS SIGNIFICANCE TO THE WORLD TRADE COMMUNITY
}

\author{
Aleksandra Jurewicz*
}

\section{INTRODUCTION}

This comment analyzes a case from the Polish Supreme Court that, because of its rigorous discussion of many fundamental matters and embodiment of the Court's effort to make its decision within the framework of the Vienna Convention, serves as a great contribution to the global CISG jurisprudence.

The United Nations Convention on Contracts for the International Sale of Goods (hereinafter called "CISG," "the Convention" or "the Vienna Convention") 1 is a relatively new law in Poland. It went into effect on June 1, 1996, and the first opinion of the Polish Supreme Court applying the Convention was not issued until December of 2003. ${ }^{2}$ At that time, the Court clearly struggled with the applicable principles embedded in the Convention and failed to discuss some crucial issues emerging from the facts. ${ }^{3}$ The Court's avoidance of a thorough analysis of outstanding issues and its other methodological weaknesses were not only in the area of the CISG; this problem extended generally to many new legal rules. ${ }^{4}$ Judges were often criticized for their formal application of written law and their resistance to fill in legal gaps and develop new legal concepts by referring to general principles

\footnotetext{
* Associate, Jones Day, Master of Law (Magister Prawa) 2003, Jagiellonian University School of Law, Cracow, Poland; LL.M. 2005, J.D. 2007, University of Pittsburgh School of Law. I would like to thank Professors Harry Flechtner and Ronald Brand of the University of Pittsburgh School of Law whose expertise in, and passion for, the CISG inspired me to pursue further studies in the field of international sales law. I also would like to thank Dr. Mateusz Pilich for sharing with me the court opinion discussed in this comment.

1. United Nations Convention on Contracts for the International Sale of Goods art. 31, U.N. Doc. A/CONF.97/18, Annex 1 (Apr. 11, 1980) [hereinafter CISG].

2. Aleksandra Jurewicz, The First Decision of Sad Najwyzszy of December 19, 2003: The Polish Supreme Court Applying the UN Convention on Contracts for the International Sale of Goods, 1 CoLUM. J. E. EUR. L. 231, 233 (2007).

3. Id. at 234 .

4. Norbert Reich, Transformation of Contract Law and Civil Justice in the New EU Member Countries-The Example of the Baltic States, Hungary and Poland, 23 Penn ST. InT'L L. Rev. 587, 622 (2005).
} 
of law. ${ }^{5}$ Since then, the Polish Supreme Court has altered its approach by utilizing interpretation methods regarding general clauses and rules. Its 2007 decision involving the CISG is the best proof of the tremendous progress that has been made by Polish judges.

The Court's approach in the case is in line with the world trade community's goal: to "maintain the Convention as a source of uniform international sales rules . . . when it is being applied by courts, arbitral tribunals and lawyers in . . . countries with diverse legal cultures. ${ }^{96}$ Having shown the legal community its skillful application of the Vienna Convention, the Court took an immense step towards changing the stereotype of Polish courts as lacking in analytical rigor.

In its 2007 decision, the Court faced the problem of constructing a buyer's right to withhold payment of the purchase price where a nonconformity of the delivered goods amounted to a fundamental breach. Further complicating matters, the buyer was at fault because he failed to inspect the goods before they were converted into another product by a third party subcontractor. As a result of this oversight and the inability to return the goods in substantially the same condition, the buyer could have been deprived of some remedies in accordance with Article 82(1). Ultimately, however, the Court derived the right to suspend performance from Article 71, which governs anticipatory breach, in conjunction with the principle of good faith embodied in Article 7(1), which regulates relations between the parties.

\section{THE CASE}

\section{A. Facts}

In January 2000, a Polish seller (Spoldzielnia Pracy “A”) and a German buyer (M.W.D. GmbH \& Co. KG) entered into a sales contract for 4,400 square meters of a specific type of leather for the purpose of manufacturing military shoes for the German army (Bundeswehr). ${ }^{7}$ The leather was delivered directly to a shoe manufacturer in Germany, and the German buyer did not inspect the goods upon their delivery. After the shoes were manufactured, the

\footnotetext{
5. Id. (citing Frank Emmert, Administrative and Court Reform in Central and Eastern Europe, 9 EuR. L.J. 288-315 (2003)).

6. Harry M. Flechtner, Funky Mussels, a Stolen Car and Decrepit Used Shoes: Non-conforming Goods and Notice Thereof Under the United Nations Sales Convention, 26 B.U. INT'L L.J. 1, 2 (2008).

7. Spoldzielnia Pracy “A” v. M.W.D. GmbH \& Co. KG, May 11, 2007, Sad Najwyzszy [Supreme Court of Poland], V CSK 456/06, available at http://cisgw3.law.pace.edu/cases/070511p1.html.
} 
German Federal Bureau for Technical Defense and Supply noticed that the goods did not conform to the specifications of the offer. On May 12, 2000, the buyer notified the seller that the goods were non-conforming, asked for a quality control certificate, and fixed an additional period of time - until May 15, 2000 - for the seller to deliver conforming goods. In the meantime, the Bundeswehr returned all the shoes (37,130 pairs). The seller refused to deliver substitute goods, and on December 17, 2002, the buyer sent the seller a declaration of avoidance of the contract. ${ }^{8}$ Consequently, the seller sued the buyer for payment of the purchase price.

\section{B. The Court's Reasoning}

In its analysis, the Supreme Court assumed that the CISG distinguishes between breach, including fundamental breach and non-conformity of the goods, and noted that common law and civil law differ as to the treatment of a breach of contract. The Court stated that there should not be a distinction between failure to perform and other breaches of contract, and furthermore, that delivery of non-conforming goods is a breach of contract. The Court explained that the rule on non-conformity as a breach stems from Article 35 of the Convention, which describes what characteristics goods must possess to comport with the contract and provides that failure to fulfill those characteristics amounts to non-conformity. However, mere non-conformity does not entitle the buyer to require delivery of substitute goods under Article 46(2) of the Convention because this remedy is available only when the lack of conformity constitutes a fundamental breach of contract under Article 25.

The Court continued that CISG scholars agree that Article 25 is one of the most difficult provisions to interpret because it includes numerous undefined terms. At the same time, this article is one of the most important provisions because the matter of a fundamental breach, judged on the circumstances of the contract and the expectations of the parties, determines which remedies are available, especially delivery of substitute goods and avoidance of contract without the requirement to give additional time to perform. Having the freedom to choose remedies, the buyer is, however, bound to the contract and should not, acting in good faith and as a reasonable person, first request delivery of substitute goods and then, not waiting for delivery, declare the

8. Even though the facts may implicate Articles 39, 49(2)(b), and 82(1) those issues were not raised by the parties or were addressed by lower courts in the Buyer's favor. See generally CISG arts. 39, 49(2)(b), and $82(1)$. 
contract avoided. In addition, the Court briefly discussed the notion of a fundamental breach, computation of damages by an objective standard, and the burden of proof.

Then, the Court turned into the principal issue, namely the buyer's right to withhold performance. It agreed with legal literature providing that when a buyer promptly requests substitute goods, a seller cannot demand payment before the goods are delivered. In the Court's opinion, this view follows the general principles of the Vienna Convention, including the right to require actual performance and concurrent exchange of performance, payment against delivery. The Court noted that the Convention does not require that the delivered goods perfectly comply with the terms of the contract, but if the seller commits a fundamental breach, he should deliver substitute goods. Furthermore, until the substitute goods are delivered, the buyer is not obliged to pay the price because the seller would otherwise receive performance even though he has not performed under the contract.

The decision acknowledged that Article 46(2) does not indicate that a request for substitute goods automatically allows a party to wait to pay the price because this provision governs only the right of the buyer to request a delivery of substitute goods. The right to suspend payment is also not directly based on Article 71, regulating the right to suspend the performance of obligations in the case of an anticipatory breach of contract whereby it becomes apparent that the other party will not perform a substantial part of his obligations. That is because a remedy is not available under Article 71 where the goods have been delivered to the buyer. Clearly, in a situation where a breach of contract becomes apparent after the goods are tendered and the risk shifts, it is difficult to talk about an anticipatory breach of contract.

Summarizing its analysis of Article 71, the Court concluded that there was no basis to directly apply this article because there was no anticipatory breach of the contract in question. However, the Court agreed with the buyer that the appellate court violated the Convention by not analyzing whether Article 71 can be applied by analogy or whether it establishes a general rule of the Convention fulfilling a gap and giving the aggrieved party a general right to withhold performance in order to force another party to perform promptly.

In the Court's view, the construction of such a rule is not only possible, but also supported by the rules of good faith and fair dealing. The Court referred to Opinion No. 5 of the CISG Advisory Council, ${ }^{9}$ which derived the 
right to withhold the performance of obligations as a result of non-conformity from Articles 71, 81(2), 85, 86(2). In addition, it reasoned that this view has been shared by some contracting states' courts. The Austrian Supreme Court, in its opinion from November 8, 2005, ${ }^{10}$ ruled on the issue of nonpayment for non-conforming goods and indicated the possibility of deriving a general right of the buyer to withhold its performance under the payment against delivery rule.

The Polish Supreme Court's conclusion was that filling in the gaps of the Convention is possible through analogy, here by analogy to Article 71, because legal literature and case law allow it for the purpose of interpreting the CISG.

The Court also disagreed with the seller that Article 80 was violated. Article 80 states that "[a] party may not rely on a failure of the other party to perform, to the extent that such a failure was caused by the first party's act or omission." "11 Accordingly, the Court reasoned that Article 80 imposes on the parties a duty of loyalty and abstention from any acts that would hinder the performance of the contract. One of the imperative elements of this article is the presence of legal causation linking the obligor's conduct and obligee's performance. Under the circumstances, the buyer's failure to pay the price was not a result of lack of mutual performance under the contract, but rather a result of the seller's failure to tender goods conforming with the terms of the contract.

The Court remanded the case and instructed the appellate court to analyze the dispute in light of the good faith rule. It also acknowledged that the buyer did not inspect the goods after they have been delivered and purchased substitute goods without avoiding the contract. The seller, however, did not show a willingness to work with the buyer to limit the consequences of nonconformity. The fact that the seller relied only on its own judgment of the quality of the goods and refused to cooperate with the buyer caused the buyer to make a cover purchase. According to the Court, these circumstances may lead to the rule of good faith which does not allow the obligee to receive what he should give to his debtor as compensation for the harm caused.

Goods or Documents (May 2005), available at http://www.cisg.law.pace.edu/cisg/CISG-AC-op5.html.

10. Oberster Gerichtshof [OGH] [Supreme Court], 4 Ob 179/05k, Internationales Handelsrecht (Austria) (Nov. 2005), available at http://cisgw3.law.pace.edu/cases/051108a3.html.

11. CISG art. 80 . 


\section{CASe Analysis}

\section{A. Interpretation of the Convention Within Its Four Corners and the Good Faith Rule-General Remarks}

Because the Vienna Convention is the product of numerous compromises between the representatives of different legal systems, it contains ambiguous provisions and undefined terms which require appropriate interpretation. ${ }^{12}$ For many conventions, uniform interpretation and application is often an unachievable ideal because the difficulties of linguistic translation are intertwined with those of different legal traditions, cultures, and practices. ${ }^{13}$ To diminish the inevitable discrepancies in the application of the CISG, Article 7(1) obligates all contracting states to interpret the Convention in light of its international character, with a view to maintaining uniformity in its application and observance of good faith in international trade. ${ }^{14}$ This autonomous method of interpretation is called a "four-corners approach" and is constantly being developed with the aid of practices and "case law" rendered by courts and arbitral tribunals of sister signatories. ${ }^{15}$ The growing body of case law applying the CISG and referencing the jurisprudence developed by other courts is key to the process of uniform interpretation of the CISG, even though the opinions of other applying authorities, often from other countries, are neither binding nor precedential in the common law sense. ${ }^{16}$ Another source of uniform interpretation and application is scholarly writings, commentaries and opinions of the CISG Advisory Council. As much as civil law judges often rely on these sources of interpretation, they are new and

12. Evelien Visser, Gaps in the CISG: In General and with Specific Emphasis on the Interpretation of the Remedial Provisions of the Convention in the Light of the General Principles of the CISG (June 1998) (unpublished LL.M thesis, University of Georgia School of Law), available at http://www .cisg.law.pace.edu/cisg/biblio/visser.html.

13. Vivian Grosswald Curran, The Interpretive Challenge to Uniformity, 15 J.L. \& Com. 175, 176 (1995) (reviewing Claude Witz, Les Premieres APPLiCATIONS JuRisPRudENTIELLES DU Droit UNiforme DE LA Vente InTERnATIONALE (1990)).

14. CISG art. 7(1).

15. Bruno Zeller, Four-Corners-The Methodology for Interpretation and Application of the UN Convention on Contracts for the International Sale of Goods (May 2003), available at http://www.cisg .law.pace.edu/cisg/biblio/4corners.html.

16. Flechtner, supra note 6 , at 2. 
rarely referred to in common law countries ${ }^{17}$ However, in recent years, a more relaxed and liberal approach to the use of doctrine has been noticed in common law systems. ${ }^{18}$

\section{Gap-Filling by Analogy}

Article 7(2) of the Convention instructs that "questions concerning matters governed by this Convention which are not expressly settled in it" should in the first instance be resolved "in conformity with the general principles on which it is based." 19 This provision indicates that the CISG presupposes gaps in the Convention which courts and tribunals should fill within the Convention's "four corners." ${ }^{20}$ Yet, it is worthy of remark that Article 7(2) does not require that all gaps be filled autonomously. Rather, if a particular gap cannot be filled by recourse to the general principles underlying the Convention, "the traditional method of determining the law applicable by virtue of the rules of private international law applies."21 Commentators agree that, even though analogy to certain provisions of the Convention is not mentioned as a means of resolving matters not settled in the CISG, it is a permissible method of interpretation and gap-filing. ${ }^{22}$ This view has been followed by the Polish Supreme Court, which demonstrated unprecedented discipline in applying Article 7(1) of the Convention and cited with approval a case from Austria and a CISG Advisory Opinion allowing such a method of gap-filling.

\section{Good Faith}

As mentioned before, Article 7(1) requires that the CISG be interpreted uniformly to promote its international character and forbids recourse to domestic principles. ${ }^{23}$ In addition, Article 7(1) points to the broad application

17. John Felemegas, Introduction to An International Approach to the United Nations Convention on Contracts For the International Sale of Goods (1980) AS Uniform Sales LaW 1, 16-17 (John Felemegas ed., 2007), available at http://www.cisg.law.pace.edu/cisg/biblio/felemegas14 .html.

18. Id. at 17 .

19. CISG art. 7(2).

20. Gert Brandner, Admissibility of Analogy in Gap-filling under the CISG (1999), http:// www.cisg.law.pace.edu/cisg/biblio/brandner.html.

21. $I d$.

22. Id.

23. CISG art. 7(1). 
of good faith in international trade. ${ }^{24}$ Thus, good faith as a principle is not only applied to the interpretation of the CISG as a whole, but it also governs the behavior of the contracting parties. ${ }^{25}$

The concept of good faith was introduced to the Polish legal system in 1990 and indirectly stems from Article 7 of the Civil Code,${ }^{26}$ which states that if certain legal consequences are viewed in light of good or bad faith, good faith is presumed.$^{27}$ In its decision, the Court adequately grasped the dual nature of the good faith principle of the CISG. It appears that good faith was the leading theme in analyzing the Convention's language, filling in its internal gaps, and judging the conduct of the parties. The Court invoked the good faith principle to determine the buyer's rights within the Convention's framework. Specifically, the Court considered whether the parties acted in good faith by acknowledging that, indeed, the buyer failed to inspect the goods, but the seller showed no willingness to mitigate the buyer's losses and stubbornly claimed that the leather was of the ordered quality when in fact it was not.

\section{B. Buyer's Rights and Remedies for Breach of Contract by the Seller}

Under the Convention, the seller is obliged to, inter alia, deliver the $\operatorname{goods}^{28}$ and to do so in compliance with the contract. ${ }^{29}$ Any breach of the seller's duty equals a failure to perform and triggers the remedies listed in Article 45(1). ${ }^{30}$

The CISG equips the buyer with different kinds of remedies which are available depending on the "severity" of the seller's breach. For example, "avoidance of the sales contract is restricted to cases in which a fundamental breach occurs, and to cases where the seller has not properly performed after the buyer granted a Nachfrist period." 31

When the seller's breach of contract is due to a lack of conformity of goods, Article 46 gives "the buyer [a] choice between two closely linked

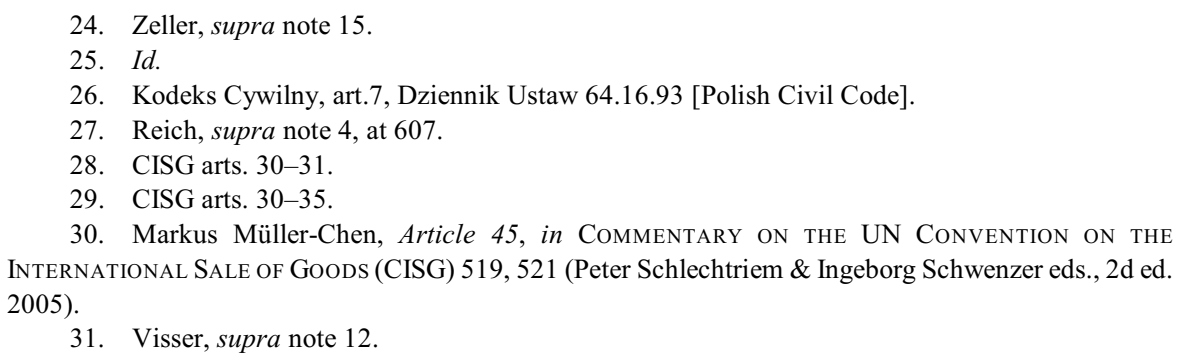


remedies: he can require for delivery of substitute goods, or he can require the seller for repair of the lack of conformity." ${ }^{32}$ However, it is worthy of remark that Article 46(2) gives the buyer the right to require delivery of substitute goods if the breach is fundamental and the request is made within a reasonable period of time. ${ }^{33}$

Finally, if the goods do not conform with the contract, the buyer may reduce the price in proportion to the diminished value of the delivered goods. ${ }^{34}$ The Convention, however, does not explicitly address the right to withhold payment of purchase price in case of breach of contract.

\section{Buyer's Right to Withhold Payment of Price}

Article 45 does not exhaustively govern the rights of the buyer; additional remedies can be derived by analogy to other provisions of the Convention. It is true that the CISG does not contain an explicit provision generally allowing one party to withhold its performance in case of the other party's breach of contract. By the same token, the buyer's right to withhold performance, including payment of the purchase price, is not excluded by the provisions governing the buyer's rights and remedies, and therefore, the majority of writers are of the opinion that such a right may be derived by analogy to Article 7(2) ${ }^{35}$ Hence, courts can construct a right of the buyer to withhold payment of the price when the performance rendered is not in conformity with the contract.

Some authors infer the buyer's general right to suspend performance upon receipt of non-conforming goods from the principle of "payment against delivery" expounded in Article 58, which mandates the payment of the price only when the goods delivered to the buyer conform with the contract. ${ }^{36}$ The reasoning behind this view is that this interpretation is compatible with the buyer's right to inspect the goods, which would otherwise have no meaning. ${ }^{37}$ Thus, if the goods delivered are not in conformity with the contract and the buyer, in accordance with Articles 46(2) and (3), requires a substitute delivery

32. Id. See CISG art. 46.

33. Id.

34. CISG art. 50.

35. Peter Schlechtriem, Article 7, in Commentary on the UN Convention on the International SALE of Goods (CISG), 108 (Peter Schlechtriem \& Ingeborg Schwenzer eds., 2d ed. 2005).

36. CISG art. 58; Müller-Chen, supra note 30, at 527.

37. Id. at 528 . 
or repairs, the buyer may withhold payment in reliance on the fact that payment is not yet due. ${ }^{38}$

The buyer's right to withhold performance may also be derived from the principles underlying Articles 71, 81(2), 85, and 86(1). ${ }^{39}$ This view has been widely accepted by civil law academics. ${ }^{40}$ On the other hand, another view, expressed by Schnyder and Straub, is that the Convention does not contain any general right for one party to withhold its performance, and if the contract is breached, the innocent party may only seek remedies contained in the Convention. ${ }^{41}$ This view is said to stem from Article 48, which entitles the seller to remedy the non-conformity of his performance and explicitly reserves for the buyer only claims for avoidance and damages, but is silent with regard to the right to refuse performance. ${ }^{42}$

Finally, the right to withhold payment may be derived from the UNIDROIT Principles, ${ }^{43}$ which are often used to supplement the gaps of the Convention. ${ }^{44}$ This approach has been adopted in 1999 by the Arbitration Court of the International Chamber of Commerce when ruling on a case involving a dispute between a Bulgarian seller and a Greek buyer. ${ }^{45}$ In that case, the buyer suspended payment alleging non-conformity of a subsequent

38. Id. at $527-28$.

39. See CISG arts. 71, 81(2); CISG art. 85 ("[The seller] is entitled to retain [the goods] until he has been reimbursed his reasonable expenses by the buyer."); CISG art. 86(1) ("[The buyer] is entitled to retain [the goods] until he has been reimbursed his reasonable expenses by the seller.").

40. Ulrich Magnus, General Principles of UN-Sales Law, 59 Rabels Zeitschrift (1995), translated at http://www.cisg.law.pace.edu/cisg/biblio/magnus.html. See also Damien Nyer, Withholding Performance for Breach in International Transactions: An Exercise in Equations, Proportions or Coercion?, 18 PaCe InT'L L. Rev. 29, 71-72 (2006); Mirghasem Jafarzadeh, Buyer's Right to Withhold Performance and Termination of Contract: A Comparative Study Under English Law, Vienna Convention on Contracts for the International Sale of Goods 1980, Iranian and Shi'ah Law (2001), http://www.cisg.law.pace.edu/cisg/biblio/jafarzadeh1.html\#p2.

41. Kommentar zUm Un-Kaufrecht ÜbereinKommen der Vereinten nationen ÜBER DEN INTERNATIONALEN WARENKAUF (CISG) [COMMENTARY ON THE UN SALES LAW] art. 48, para. 55 (Heinrich Honsell, ed., 1997) cited in Oberster Gerichtshof [Supreme Court] Nov. 8, 2005, 4 Ob 179/05k (Austria), available at $\mathrm{http}: / / \mathrm{cisgw} 3.1 \mathrm{aw}$. pace.edu/cases/051108a3.html.

42. CISG art. 48.

43. Int'L Inst. For the Unification of Private Law, Unidroit Principles of International COMMERCIAL CONTRACTS art. 7.1.3 (2004) ("Where the parties are to perform simultaneously, either party may withhold performance until the other party tenders its performance; Where the parties are to perform consecutively, the party that is to perform later may withhold its performance until the first party has performed.").

44. Nyer, supra note 40 , at $79-81$.

45. Goods Installments (Bulg. v. Greece), Case No. 8547, 28 Y.B. Сом. АrB. 27, 35 (2003) (Ct. of Arb. of the Int'l Chamber of Com.), available at http://cisgw3.law.pace.edu/cases/998547i1.html (proceeding under the CISG's predecessor, the Uniform Law on the International Sale of Goods, which for these purposes is similar in principle). 
shipment after several thousand tons of conforming goods had been delivered. ${ }^{46}$ The Court agreed with the buyer that it could suspend payment until the parties agree on the nature of the alleged non-conformity on the basis of Article 7.1.3 of the UNIDROIT Principles because the ULIS, like the current CISG, contained no general rule allowing a party to suspend performance. $^{47}$

\section{Polish Court's Construction of the Buyer's Right to Withhold Payment}

In this 2007 opinion, the Polish Supreme Court stated that the right to suspend payment cannot be inferred from Article 46(2) because it governs the buyer's right to request delivery of substitute goods if the delivered goods do not conform with the terms of the contract. Similarly, the general right to suspend performance could not be directly derived from Article 71 because it regulates an anticipatory breach of contract. However, the Court held that Article 71 serves as a basis for deriving, by analogy, the right to suspend payment. In order to justify this analogy, the Court stated that such practice is acceptable and compatible with the good faith principle as it promotes uniformity and "uncovers" general principles underlying the Convention. This view is in line with that of a leading CISG expert, who opined that such a general right can be developed from a principle embodied in Article 71. ${ }^{48}$

What is unique about this decision is that the Court did not rely on Article 58 , which is the strongest basis to infer the general right to suspend performance and directly touches on the issue of payment of the purchase price. This may be explained, however, by the facts of the case, which clearly did not fall under the rule embodied in Article 58(3) which allows the buyer to withhold the payment of the purchase price until he has had an opportunity to examine the goods. As the facts in this case indicate, the buyer and its subcontractor had such an opportunity but failed to inspect the goods after they were delivered. This major failure on part of the buyer was nevertheless excused in accordance with the good faith principle because the seller's fault was greater than the buyer's in that he showed no willingness to remedy the non-conformity and accordingly mitigate damages. Thus, under the circumstances, the Court had to show more creativity in finding a solution that

\footnotetext{
46. $I d$.

47. Id. at 25 .

48. Schlechtriem, Article 4, supra note 35, at 73.
} 
would protect the aggrieved buyer and prevent the stubborn seller from receiving more than he should have gotten under the contract.

The final outcome is correct even though, at the first glance, one may feel sympathetic to the seller who delivered the ordered leather, which was accepted without inspection and converted into military shoes before nonconformity was discovered. Yet in the end, the seller was left with over 30,000 shoes which could not be easily resold and did not get payment from the buyer. It is true that the restitution issue could have arisen in the case, but that question was not before the Supreme Court which had to address the question of whether the seller was really entitled to the payment of the purchase price after having committed a fundamental breach and shown no willingness to cooperate.

Overall, the Polish Supreme Court properly held that the buyer, who demanded substitute delivery under Article 46, also had the right to withhold the payment of the price until such time as the seller performed its obligations in conformity with the contract.

\section{CONCLUSION}

This case demonstrates that the Polish Supreme Court closely observed the mandate of Article 7(1) to deliver a uniform, "international" interpretation of the Convention. Moreover, the Court's lengthy remarks on such concepts as fundamental breach, avoidance of a contract and seller's remedies in general have indispensable value to subordinate national courts which often have no means to reach to and use opinions in foreign languages. By undertaking an extensive analysis, the Court gives guidance to lower courts and promotes uniformity at the national level which will later result in better predictability of outcomes on a global scale. The approach taken by the Court shows tremendous progress in building useful international jurisprudence since its first decision in 2003, where the Court abstained from discussing several issues that were at the heart of the case. Hopefully, the Court will maintain its interpretational skills and will inspire lower courts to apply the CISG with the same rigor so that, in the near future, CISG jurisprudence from Poland will serve as a reliable source for other courts and arbitration tribunals around the globe. 